\title{
Surgical Diathermy is not suitable for Vascular Tissue Welding
}

Maj N B Corner

FRCS, RAMC

Surgical Senior Registrar

R E Smith

$\mathrm{PhD}$

Senior Research Fellow

Professorial Surgical Unit, St Bartholowmew's Hospital, London ECIA 7BE

SUMMARY: The possibility of using radiofrequency energy (RFE) to produce a sutureless anastomosis is $\vec{\circ}$ attractive both to the military surgeon and on the grounds of cost and simplicity. To investigate this, fresh rabbit aorta was divided lengthways into $4 \mathrm{~mm}$ strips and apposed, intima-to-itima. A Valleylab Force 30 Electrosurgers? machine supplied RFE at $500 \mathrm{kHz}$. The energy was applied using standard bipolar forceps and 121 attempts were made to weld the tissue. Seventy seven welds resulted of which 36 were able to withstand a distraction force of greater than $0.1 \mathrm{~N}$ : the strongest weld was disrupted at $0.35 \mathrm{~N}$. Intact tissue withstood a distraction force of greater' than $2 \mathrm{~N}$, whilst sutured joints disrupted at $0.97 \mathrm{~N}$. It is concluded therefore that radiofrequency energy at $500 \mathrm{kH}{ }^{\vec{p}}$ does not satisfactorily weld vascular tissue.

\section{Introduction}

The construction of a conventionally sutured vascular anastomosis is a skilled, time consuming task, unsuited to the military environment. It results in a rigid, fibrotic join prone to neo-intimal hyperplasia and restenosis.

Over many years, numerous attempts have been made to overcome these flaws by the development of practicable sutureless vascular anastomotic techniques. Generally one of the three main joint configurations (Fig 1) were used.

Over hundred years ago Abbe described the use of a glass intraluminal stent to produce a butt joint (1). Subsequently, soluble intraluminal stents $(2,3,4,5)$ and cyanoacrylate adhesives (6) have also been used. Various stapling devices have also been described $(7,8)$ but they were mechanically complex and their use has not become commonplace.

Recently many groups have demonstrated the construction of sutureless vascular anastomoses using laser energy to weld the tissue together, Wavelengths from $488 \mathrm{~nm}$ (Argon ion) (9,10), $532 \mathrm{~nm}$ (KTP) (11), $1.9 \mu \mathrm{m}$ (Nd:YAG) $(12,13,14)$ to $10.6 \mu \mathrm{m}\left(\mathrm{CO}_{2}\right)$ $(11,15,16,17)$ have been used with varying degrees of success. The methods used have required stay sutures. Histological examination of the laser welds shows transmural necrosis with preservation of the elastic lamina and an initial weld composed of fibrin (15).

It is unlikely that any method that requires the insertion of stay sutures or employs devices as costly as surgical lasers will achieve universal acceptance, certainly such techniques would not be applicable in a war zone. The use of lasers may be unnecessary, since closely apposing tissue surfaces and raising their temperature to $55^{\circ} \mathrm{C}$ for three hours results in collagen bonding (18). Furthermore it has been shown that longitudinal venotomies an arteriotomies can be "welded" using conventional surgical diathermy apparatus, and that microscopic fusion of collagen resulted, provided the correct temperature attained $(19,20)$. Strips of human aorta separated throigt the medial layer have been re-approximated uswi radiofrequency energy (RFE) (21). Exceeding optimum temperature leads to complete tissue disruption and charring $(20,21)$. For tissue welding to becont

Butt

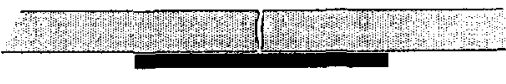

Lapped

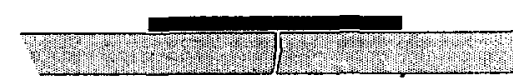
$\overrightarrow{\overrightarrow{0}}$

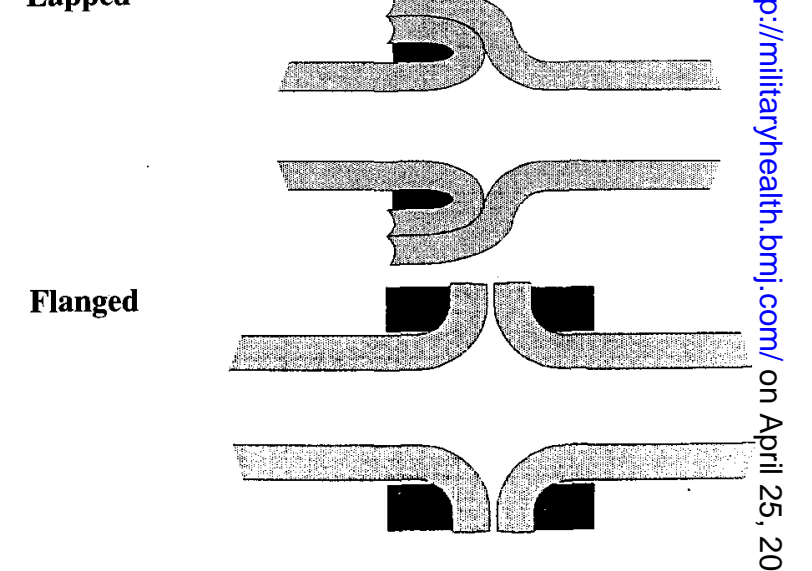

Fig 1. The three major types of anastomosis. Stents or clampE్ are shown as solid. 
viable technique for vascular anastomosis, a number of requirements must be met in comparison to a sutured anastomosis.

1 The welded joint must have equivalent rates of leakage, rupture and aneurysm formation.

2 The anastomosis must take no longer to fashion.

3 There should be no greater tissue reaction than the significant response seen with standard sutured anastomoses $(15,22,23)$.

4 Improved compliance of the anastomosis should be achieved.

5 The unit cost of a welded anastomosis should not greatly exceed that of suturing.

This set of conditions will preclude general acceptance of laser welding. Radiofrequency welding using conventional diathermy apparatus has been shown to meet the third condition (20) and meets the last (cost).

An attempt was made to develop a rapid tissue welding technique for end-to-end, and end-to-side, anastomoses in arterial tissue using RFE. A Valleylab Force 30 model surgical diathermy unit (Pfizer Hospital Products Group, London) was used. This commonly available unit delivers energy at $500 \mathrm{kHz}$.

\section{Methods}

Rabbit aorta and iliac artery was harvested and used within four hours of death. The animals were housed and sacrificed according to the Animals (Scientific Procedures) Act, 1986. The tissue was washed and stored in $0.9 \%$ saline. The vessels were "cleaned" of most loose tissue and adventicia. They were opened along their length and cut into strips about $4 \mathrm{~mm}$ wide.

\section{Diathermy Forceps}

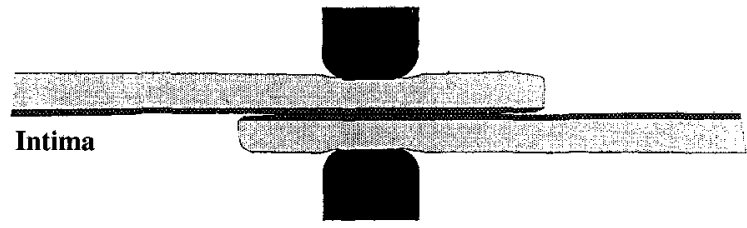

Fig 2. The intima-to-intima lap weld used in this study. The diathermy forceps are shown as solid.

Intima-to-intima lap welds (Fig 2) were made by applying the standard bipolar output across the joint using the microsurgical diathermy forceps supplied with the machine. Having become proficient in the use of the equipment 121 welds were attempted. Generator settings of up to 20 (Watts) were used for measured times of around 5 seconds. This period is convenient for timing and surgical practice.

The overlap of the tissue was $2-4 \mathrm{~mm}$, and gentle interfacial pressure was applied with the forceps. A weld was deemed to have been made if the tissues remained in apposition after the removal of the forceps.
Five joints were constructed for comparison by approximating two $4 \mathrm{~mm}$ strips using a conventional technique with three $6 / 0$ prolene sutures.

For a second series a toolmaker's clamp was modified by fixing strips of perspex to each of its jaws. Copper wire (18swg) was laid in half round channels running along the perspex and held in place with epoxy resin. The protruding section of the copper wire was filed down level with the surface of the perspex and the entire surface finished by gentle abrasion with fine emery paper. This ensured that the copper wire did not divide the tissue when pressure was applied.

Strips of arterial tissue, about $4 \mathrm{~mm}$ wide, were laid intima to intima on the lower jaw of the clamp with an overlap of about $5 \mathrm{~mm}$. This overlap was chosen as the minimum required to prevent extrusion of the tissue from the jaws of the clamp. The pressure applied to the tissue was set by adjusting the clamping screws to finger tightness. RFE was applied via the inlaid copper wire.

In a third series an attempt was made to try to localise the heat generated at the tissue interface by coating the intimae of the vessels with a thin film of soft yellow paraffin BPC.

After welding the tissue was placed in physiologicat saline for an arbitrary 5-10 s to rehydrate and thero mounted on a jig to determine the static strength of the weld. The tissue was hung vertically and a slowly increasing weight was applied. The minimum measurable weight applied by this jig was $10.5 \mathrm{~g}$, a distraction force oB $0.1 \mathrm{~N}$.

The output power of the Valleylab Electrosurgica generator into loads of between 50 and $500 \mathrm{Ohms}$ was determined over a range of output settings (2-50) using an RF302 Electrosurgery analyser (Bio-Tek Instruments Inc., Winooski,VT, USA).

\section{Results}

The output power of the Valleylab Electrosurgical generator did not vary greatly with load. It was maximal at $100 \mathrm{Ohms}$, and the co-efficient of variation of delivered power with loads between 50 and $500 \mathrm{Ohms}$ at a setting of 10 was $12 \%$.

With little error the diathermy setting is equivalent to output power (Watts) into 100 Ohms. A set of typical output waveforms are shown in Figure 3, demonstrating that although frequency remains constant at $500 \mathrm{kHz}$ the wave shape varies with load.

On the test jig the maximum weight of $210 \mathrm{~g}(2.06 \mathrm{~N})$ failed to disrupt the uncut strips of rabbit aorta.

The joints constructed using the conventional technique with $6 / 0$ prolene sutures recorded a mean disruption weight of $99 \mathrm{~g}(0.97 \mathrm{~N})$. The joints yielded significantly at about $90 \%$ of the final disruption strength. 
Diathermy output waveforms setting: 20

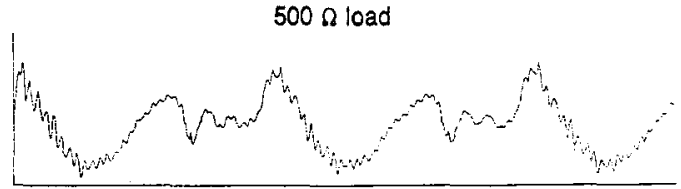

$300 \Omega \mathrm{load}$
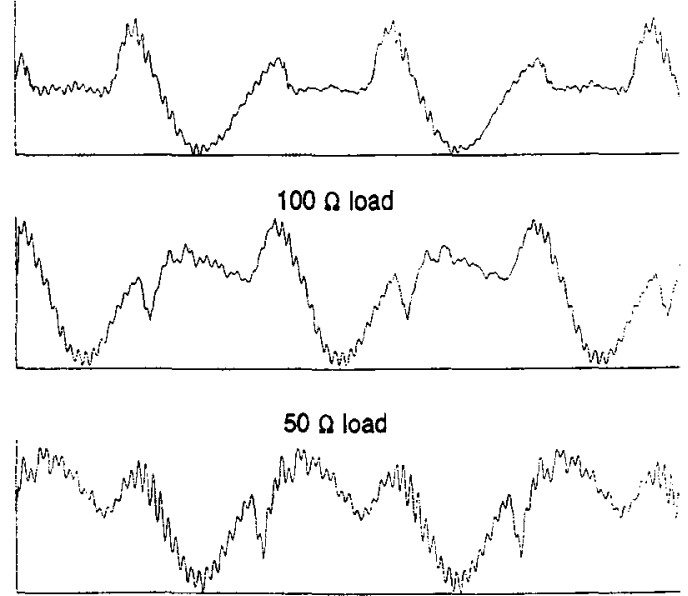

Fig 3. Typical output waveforms from the diathermy generator with a setting of 20 (approximately $20 \mathrm{~W}$ ) with loads between 500 and 50 Ohms. The waveforms were obtained from the monitor output of the RF302 electrosurgery analyser.

Table 1

Tissue welding using bipolar forceps

\begin{tabular}{|c|c|c|c|c|c|c|}
\hline \multirow{2}{*}{$\begin{array}{l}\text { *Energy } \\
\text { delivered } \\
\text { (J) }\end{array}$} & \multirow{2}{*}{$\begin{array}{c}\text { Generator } \\
\text { setting }\end{array}$} & \multirow{2}{*}{$\underset{\text { (s) }}{\text { Time }}$} & \multirow{2}{*}{$\begin{array}{l}\text { Number } \\
\text { of welds } \\
\text { attempted }\end{array}$} & \multicolumn{3}{|c|}{ Weld strength } \\
\hline & & & & $\begin{array}{c}\text { No } \\
\text { weld }\end{array}$ & $<10 \mathrm{~g}$ & $>10 \mathrm{~g}$ \\
\hline $10-120$ & 2 & $5-60$ & 20 & 20 & - & - \\
\hline 8 & 4 & 2 & 2 & 2 & - & - \\
\hline 10 & 10 & 1 & 3 & 2 & 1 & - \\
\hline 15 & 3 & 5 & 10 & 2 & 8 & - \\
\hline 15 & 7.5 & 2 & 1 & - & 1 & - \\
\hline 20 & 4 & 5 & 2 & 2 & - & - \\
\hline 20 & 10 & 2 & 5 & 1 & 2 & 2 \\
\hline 25 & 5 & 5 & 25 & 6 & 11 & 8 \\
\hline 30 & 6 & 5 & 3 & 2 & - & 1 \\
\hline 30 & 7.5 & 4 & 2 & - & 2 & - \\
\hline 37.5 & 7.5 & 5 & 25 & 4 & 6 & 15 \\
\hline 50 & 10 & 5 & 15 & 1 & 8 & 6 \\
\hline 80 & 4 & 20 & 2 & 2 & - & - \\
\hline 100 & 20 & 5 & 6 & - & 2 & 4 \\
\hline & & & 121 & 44 & 41 & 36 \\
\hline
\end{tabular}

* Energy delivered is calculated on the assumption that the load resistance is $100 \mathrm{Ohms}$.
The results from the first series of welds are shown in

Table 1 and are summarised as follows:

44 attempts at welding failed completely;

41 welds failed at distraction force of $<10 \mathrm{~g}$ weigh 5 $(0.1 \mathrm{~N})$ :

36 welds failed at distraction forces of $11-36 \mathrm{~g}$ weight (0.11-0.35N).

No weld achieved a strength of $50 \%$ that of ano equivalent sutured join.

Tissue bonding did not occur with a generator setting of 2 regardless of the time over which energy was applied $\mathbb{\nabla}$ Settings of 3 resulted in 8 welds none of which resisted an distraction force of $0.1 \mathrm{~N}(10 \mathrm{~g})$. At settings between 3 $^{\infty}$ and 10 , only 8 welds were able to resist a distraction force? of $0.3 \mathrm{~N}(30 \mathrm{~g})$ or more. Energy delivered at a setting of $\overrightarrow{\mathrm{F}}$ 10 of $5 \mathrm{~s}$ resulted in 8 welds which failed to resist $0.1 \mathrm{~N}$, and 6 welds which disrupted between $0.13 \mathrm{~N}(13.5 \mathrm{~g})$ and $0.35 \mathrm{~N}(35.5 \mathrm{~g})$. Statistical analysis using multiple linear regression failed to demonstrate any significant effects.

A noticeable phenomenon was the preferential adhesion $\vec{b}$ of the tissue to the diathermy forceps. Sometimes "weld" appeared to have developed between each piece of tissue and the adjacent diathermy forceps blade, with little or no adhesion between the two pieces of tissue. Some poor quality welds were destroyed by the action of removing the forceps.

The results of tissue welds produced by the clamp wक्ष equally erratic. Twenty welds were attempted. Thoㅇ welds of $0.12 \mathrm{~N}$ and $0.39 \mathrm{~N}$ breaking force were forged with 4 welds unable to resist $0.1 \mathrm{~N}$ and 14 failures. Powẹp settings between 3 and 20 were used. The higher poer settings caused unacceptable tissue shrinkage.

The results are shown in Table 2. No welds were obtained by simply clamping the tissue.

In the third series the effect of thinly coating the intima with soft yellow paraffin appeared to be an increase in the heat generated for a given power delivery, but tissue welds remained weak and associated with excessive widespread tissue shrinkage. Of 16 welds fashioned only one could resist the mimimum $10 \mathrm{~g}$ weight, and this weld disrupted at $20 \mathrm{~g}(0.19 \mathrm{~N})$. the results are shown in Table 3.

\section{Discussion}

The breaking weight of uncut strips of arterial tissue $\mathrm{mm}$ wide should approximate to $400 \mathrm{~g}$, the ultimates longitudinal tensile strength of aorta being $1.7 \mathrm{MPa}(24) 3$ This is consistent with our finding. The strength of thes welded anastomosis should be comparable with that of $\mathfrak{z}^{2}$ sutured join $(100 \mathrm{~g})$. However, the best welded joirg required only $40 \mathrm{~g}$ to disrupt, and this was accompanied by gross tissue shrinkage and distortion. Previous work? $(19,20)$ used diathermy apparatus working at $3-10 \mathrm{MH} \pi$ and could produce a tissue weld which repaired a short longtitudunal arteriotomy or venotomy that sometimes would withstand arterial blood pressure immediately. Irw most cases two or more attempts were necessary to 
achieve haemostasis. A significant mortality due to late haemorrhage was recorded in those animals in which the procedure was technically successful.

Using the present diathermy apparatus, tissue welding produces inconsistent results with poor strength and a large proportion of failures. The use of RF tissue welding may have a place as an adjuvant to other techniques to form a haemostatic seal in a pre-formed anastomosis. We conclude that tissue welding, using a commercially available bipolar diathermy operating at $500 \mathrm{kHz}$, is an unsatisfactory technique.

Table 2

Tissue Welding using modified approximation clamp

\begin{tabular}{|c|c|c|c|c|c|}
\hline \multirow{2}{*}{$\begin{array}{c}\text { * Energy } \\
\text { delivered } \\
(J)\end{array}$} & \multirow{2}{*}{$\begin{array}{c}\text { Generator } \\
\text { setting (for } 5 \mathrm{~s} \text { ) }\end{array}$} & \multirow{2}{*}{$\begin{array}{c}\text { Number } \\
\text { of welds } \\
\text { attempted }\end{array}$} & \multicolumn{3}{|c|}{ Weld strength } \\
\hline & & & $\begin{array}{l}\text { No } \\
\text { weld }\end{array}$ & $<10 \mathrm{~g}$ & $>10 \mathrm{~g}$ \\
\hline 15 & 3 & 2 & & 2 & \\
\hline 25 & 5 & 6 & 4 & 2 & \\
\hline 37.5 & 7.5 & 8 & 8 & & \\
\hline 50 & 10 & 2 & 2 & & \\
\hline 100 & 20 & 2 & & & 2 \\
\hline & & 20 & 14 & 4 & 2 \\
\hline
\end{tabular}

* Energy delivered is calculated on the assumption that the load resistance is $100 \mathrm{Ohms}$.

Table 3

Tissue Welding using paraffin jelly coating

\begin{tabular}{|c|c|c|c|c|c|}
\hline \multirow{2}{*}{$\begin{array}{c}* \text { Energy } \\
\text { delivered } \\
(\mathrm{J})\end{array}$} & \multirow{2}{*}{$\begin{array}{c}\text { Generator } \\
\text { setting (for } 5 \mathrm{~s} \text { ) }\end{array}$} & \multirow{2}{*}{$\begin{array}{l}\text { Number } \\
\text { of welds } \\
\text { attempted }\end{array}$} & \multicolumn{3}{|c|}{ Weld strength } \\
\hline & & & $\begin{array}{c}\text { No } \\
\text { weld }\end{array}$ & $<10 \mathrm{~g}$ & $>10 \mathrm{~g}$ \\
\hline 10 & 2 & 5 & 3 & 2 & \\
\hline 15 & 3 & 5 & 3 & 2 & \\
\hline 25 & 5 & 10 & 1 & 7 & 2 \\
\hline 37.5 & 7.5 & 5 & 2 & 3 & \\
\hline & & 25 & 9 & 14 & 2 \\
\hline
\end{tabular}

* Energy delivered is calculated on the assumption that the load resistance is 100 Ohms.

\section{REFERENCES}

1. LeE S, Wong, Orloff M J, Nahum A M. A review of vascular anastomosis with mechanical aids and nonsuture techniques. Head Neck Surg, 1980; 3: 5865.

2. SMITH $S$. The soluble rod as an aid to vascular anastomosis. Arch Surg 1940; 41: 1004-7.

3. Tibis D J, Leslie W G. Arterial replacement with minimal interruption of blood flow. Lancet, 1958; i: 292-4.

4. Ballinger W F, Fineberg C, Figlio D. Repair of small blood vessels with minimum interruption of flow. J Surg Res, 1963; 3: 475-8.

5. Yamagata S, Handa $\mathrm{H}$, Taki W, Yonekawa Y, IKADA Y, IWATA H. Experimental nonsuture anast- mosis using soluble PVA tube and plastic adhesive. J Microsurg, 1979; 1: 208-15.

6. Takenaka H, Esato K, Oharam M, Zempo $\mathrm{N}$ Sutureless anastomosis of blood vessels using cyanoacrylate adhesives. Jpn J Surg, 1992; 22: 46-54.

7. ANDROSOV P I. A new method of surgical treatmen of blood vessel lesions. Arch Surg, 1956; 73: 902-10.

8. INOKUCHI K. A new type of blood vessel suturing apparatus. Arch Surg, 1958; 77: 954-7.

9. Lawrence P F, Ke Li, Merrell S W, Goodman G R. A comparison of absorbable suture and argon laser welding for lateral repair of arteries. J Vasc Surg, 1991; 14: 183-9.

10. VANCE C A, SPYT T J, FISHER J. Laser-assisted repair. in the rat abdominal aorta. Laser Med Sci, 1990; 5: $\overrightarrow{\vec{\omega}}$. 51-60.

11. SAMONTE B R, FRIED M P. Laser-assisted microvascular anastomosis using $\mathrm{CO}_{2}$ and KTP/532 Lasers. Lasers Surg Med, 1991; 11: 511-6.

12. Kung R T V, Zelt D T, Stewart R B, LaMuraglia G M. $1.9 \mu \mathrm{m}$ absorption characteristics: effect on vascular welding. Lasers Surg Med 1992; Suppl 4: 78.

13. Shapiro S, Sartorius C, SANDERs S, Clark S Microvascular end-to-side arterial anastomosis uside the Nd: YAG laser. Neurosurgery, 1989; 25: 584-9. ते

14. Burger R A, Gerharz C-D, Kuppers P, ENGelmas U. Laser welded vascular anastomosis. Urol Res 1988; 16: 127-31.

15. Chow J W M, Flemming A F S. Laser assisted micro vascular anastomoses: a histological study. Lasex Med Sci, 1990; 5: 281-7.

16. Flemming a F $\mathbf{S}$, Colles $\mathbf{M}$ J, Guillianotti $\mathbf{R}$, Brough M D, Bown S G. Laser assisted microvascular anastomosis of arteries and veins: laser tissue welding. Br J Plast Surg, 1988; 41: 378-88.

17. Dalsing M C, PaCKer C S, KuepPers P, Griffiths S L, DAvIS T E. Laser and suture anastomosis: passive compliance and active force production. Lasers Surg Med 1992; 12: 190-8.

18. Fenner J, Moseley H, Martin W, Wheatley D J. Strength of tissue bonds as a function of surface apposition. Lasers Med Sci, 1992; 7: 375-9.

19. Sigel B, ACEVAdo F J. Electrocoaptive union of blood vessels. A preliminary study. J Surg Res 1962; 3: $90-6$.

20. SiǴEL B, DunN M R. Mechanism of blood vessel closure by high frequency electrocoagulation. Surg $ᄋ$ Gynecol Obstet, 1965; 121: 823-31.

21. Becker G J, Lee B I, Waller B F, et al. Radio-O frequency balloon angioplasty rationale and proof of $\bar{D}$ principal. Invest Radiol, 1988; 23: 810-7.

22. Cikrit D F, Dalsing M C, Weinstein T S, Palmer $\mathrm{K}$, LALKA S G, UNTHANK J L. $\mathrm{CO}_{2}$-welded venous anatomosis: enhancement of weld strength with $\mathrm{O}$ heterologous fibrin glue. Lasers Surg Med, 1990; 10: 584-90.

\section{.}


23. BaXter T J, O'Brian B, Henderson P N, Bennett R C. The histopathology of small vessels following microvascular repair. Br J Surg, 1972; 59: 617-22.
24. Duck F A. Physical properties of tissue, London: Academic Press, 1990. 